\title{
Synthesis and structural studies of dimethyltin(IV) 5-[(E)-2-(aryl)-1-diazenyl)quinolin-8-olates
}

Basu Baul, Tushar S ; Mizar, Archana ; Eng, George ; Far, Rowan ; Linden, Anthony

\begin{abstract}
A series of cis-bis5-[(E)-2-(aryl)-1-diazenyl]quinolin-8-olatodimethyltin(IV), Me2Sn(L)2, and chloro-5-[(E)-2-(aryl)-1-diazenyl] quinolin-8-olatodimethyltin(IV), $\mathrm{Me} 2 \mathrm{SnCl}(\mathrm{L})$, complexes have been synthesized by reacting the sodium salts of 5-[(E)-2-(aryl)-1-diazenyl)quinolin-8-ol (LH) and dimethyltin dichloride in 2:1 and 1:1 molar ratios, respectively. These complexes have been characterized by $1 \mathrm{H}$, 13C, 119Sn NMR in solution and by IR and 119Sn Mössbauer spectroscopy in the solid state. The structures of two of the dimethyltin(IV) complexes, viz., Me2Sn(L2)2 (2) and $\mathrm{Me} 2 \mathrm{SnCl}(\mathrm{L} 3)$. C7H8 (6) $(\mathrm{L} 2=5$-[(E)-2-(4 -methoxyphenyl)-1-diazenyl)quinolin-8-olate, L3 = 5-[(E)-2-(4 ethoxyphenyl)- 1diazenyl)quinolin-8-olate), were determined by single crystal X-ray diffraction. In general, the Me2Sn(L)2 complexes were found to adopt a distorted cis-octahedral arrangement, while $\mathrm{Me} 2 \mathrm{SnCl}(\mathrm{L})$ complexes have a distorted trigonal bipyramidal coordination geometry around the tin atom in solution and in the solid state.
\end{abstract}

DOI: https://doi.org/10.1080/00958972.2013.769528

Posted at the Zurich Open Repository and Archive, University of Zurich

ZORA URL: https://doi.org/10.5167/uzh-76758

Journal Article

Accepted Version

Originally published at:

Basu Baul, Tushar S; Mizar, Archana; Eng, George; Far, Rowan; Linden, Anthony (2013). Synthesis and structural studies of dimethyltin(IV) 5-[(E)-2-(aryl)-1-diazenyl)quinolin-8-olates. Journal of Coordination Chemistry, 66(5):813-825.

DOI: https://doi.org/10.1080/00958972.2013.769528 
This article was downloaded by: [North Eastern Hill University]

On: 24 January 2013, At: 19:57

Publisher: Taylor \& Francis

Informa Ltd Registered in England and Wales Registered Number: 1072954 Registered office: Mortimer House, 37-41 Mortimer Street, London W1T 3JH, UK

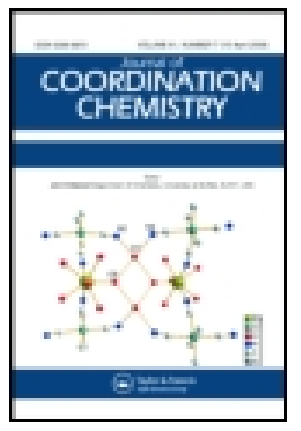

\title{
Journal of Coordination Chemistry
}

Publication details, including instructions for authors and subscription information:

http:// www.tandfonline.com/loi/gcoo20

\section{Synthesis and structural studies of dimethyltin(IV) 5- [(E)-2-(aryl)-1-diazenyl)quinolin-8-olates}

\author{
TUSHAR S. BASU BAUL ${ }^{a}$, ARCHANA MIZAR ${ }^{a}$, GEORGE ENG ${ }^{b}$, ROWAN FAR ${ }^{b}$ \& ANTHONY \\ LINDEN $^{\mathrm{C}}$ \\ a Department of Chemistry, North-Eastern Hill University, NEHU Permanent Campus, \\ Umshing, Shillong, 793 022, India \\ ${ }^{\mathrm{b}}$ Department of Chemistry and Physics, University of the District of Columbia, 4200 \\ Connecticut Avenue , DC 20008, NW, Washington, USA \\ ${ }^{c}$ Institute of Organic Chemistry, University of Zurich, Winterthurerstrasse $190, \mathrm{CH}-8057$ \\ Zurich, Switzerland \\ Accepted author version posted online: 24 Jan 2013.
}

To cite this article: TUSHAR S. BASU BAUL, ARCHANA MIZAR, GEORGE ENG, ROWAN FAR \& ANTHONY LINDEN (2013): Synthesis and structural studies of dimethyltin(IV) 5-[(E)-2-(aryl)-1-diazenyl)quinolin-8-olates, Journal of Coordination Chemistry, DOI: 10.1080/ 00958972.2013.769528

To link to this article: http:// dx.doi.org/ 10.1080/00958972.2013.769528

Disclaimer: This is a version of an unedited manuscript that has been accepted for publication. As a service to authors and researchers we are providing this version of the accepted manuscript (AM). Copyediting, typesetting, and review of the resulting proof will be undertaken on this manuscript before final publication of the Version of Record (VoR). During production and pre-press, errors may be discovered which could affect the content, and all legal disclaimers that apply to the journal relate to this version also.

\section{PLEASE SCROLL DOWN FOR ARTICLE}

Full terms and conditions of use: http://www.tandfonline.com/page/terms-and-conditions

This article may be used for research, teaching, and private study purposes. Any substantial or systematic reproduction, redistribution, reselling, loan, sub-licensing, systematic supply, or distribution in any form to anyone is expressly forbidden.

The publisher does not give any warranty express or implied or make any representation that the contents will be complete or accurate or up to date. The accuracy of any instructions, formulae, and drug doses should be independently verified with primary sources. The publisher shall not be liable for any loss, actions, claims, proceedings, demand, or costs or damages whatsoever or howsoever caused arising directly or indirectly in connection with or arising out of the use of this material. 


\title{
Synthesis and structural studies of dimethyltin(IV) 5-[(E)-2-(aryl)-1- diazenyl)quinolin-8-olates
}

\author{
TUSHAR S. BASU BAUL* $\dagger$, ARCHANA MIZAR $\dagger$, GEORGE ENG $\ddagger$, ROWAN FAR $\ddagger$ and \\ ANTHONY LINDEN*§
}

$\dagger$ Department of Chemistry, North-Eastern Hill University, NEHU Permanent Campus, Umshing, Shillong 793 022, India

$\ddagger$ Department of Chemistry and Physics, University of the District of Columbia, 4200 Connecticut Avenue, NW, Washington, DC 20008, USA

§Institute of Organic Chemistry, University of Zurich, Winterthurerstrasse 190, CH-8057 Zurich, Switzerland

A series of cis-bis $\left\{5-[(E)-2\right.$-(aryl)-1-diazenyl]quinolinolato $\}$ dimethyltin(IV), $\mathrm{Me}_{2} \mathrm{Sn}(\mathrm{L})_{2}$ and chloro\{5-[(E)-2-(aryl)-1-diazenyl]quinolinolato $\}$ dimethyltin(IV), $\mathrm{Me}_{2} \mathrm{SnCl}(\mathrm{L})$ complexes has been synthesized by reacting sodium salts of 5-[(E)-2-(aryl)-1-diazenyl)quinolin-8-ol (LH) and dimethyltin dichloride in 2:1 and 1:1 molar ratios, respectively. These complexes have been characterized by ${ }^{1} \mathrm{H},{ }^{13} \mathrm{C},{ }^{119} \mathrm{Sn}$ NMR in solution and by IR and ${ }^{119} \mathrm{Sn}$ Mössbauer spectroscopy in the solid state. Structures of two of the dimethyltin(IV) complexes, viz., $\mathrm{Me}_{2} \mathrm{Sn}\left(\mathrm{L}^{2}\right)_{2}$ (2) and $\mathrm{Me}_{2} \mathrm{SnCl}\left(\mathrm{L}^{3}\right) \cdot \mathrm{C}_{7} \mathrm{H}_{8}(\mathbf{6})(\mathrm{L}=5$-[(E)-2-(aryl)-1-diazenyl)quinolinolates: aryl = 4'-methoxyphenyl$\left(\mathrm{L}^{2} \mathrm{H}\right)$ and 4 '-ethoxylphenyl- $\left(\mathrm{L}^{3} \mathrm{H}\right)$ were determined by single crystal $\mathrm{X}$-ray diffraction. The complexes $\mathrm{Me}_{2} \mathrm{Sn}\left(\mathrm{L}^{2}\right)_{2}$ were found to adopt distorted cis-octahedral arrangement, while $\mathrm{Me}_{2} \mathrm{SnCl}(\mathrm{L})$ have a distorted trigonal bipyramidal coordination geometry around tin in solution and solid state.

Keywords: 5-[(E)-2-(aryl)-1-diazenyl]quinolin-8-ol; dimethyltin(IV) complexes; NMR; ${ }^{119} \mathrm{Sn}$ Mössbauer; Crystal structures

\section{Introduction}

We have been concentrating on coordination chemistry of organotin(V) 5-[(E)-2-(aryl)-1diazenyllquinolinolate(s) because of their potential cytotoxic properties and structural diversity [1-5]. This includes detailed study of diorganotin(IV) bis\{5-[(E)-2-(aryl)-1diazenyl]quinolinolates , with the crystal structure determinations of $\mathrm{R}_{2} \mathrm{SnL}_{2}$ complexes, where $\mathrm{R}={ }^{n} \mathrm{Bu}[3], \mathrm{Ph}[2,4]$ and $\mathrm{Bz}[1]$, revealing molecules with a highly distorted octahedral coordination of tin by bidentate quinolin-8-olate groups and essentially cis- $\mathrm{R}$ groups

*Corresponding authors. Email: basubaul@nehu.ac.in, basubaul@ hotmail.com (T.S. Basu Baul); alinden@oci.uzh.ch (A. Linden) 
(scheme 1, (i)). Structural information on $\mathrm{R}_{2} \mathrm{SnX}(\mathrm{L})$ complexes is also available e.g. $\mathrm{R}={ }^{n} \mathrm{Bu}$; $\mathrm{X}=\mathrm{Cl}, \mathrm{L}=5-[(E)-2-(4-m e t h o x y p h e n y l)-1-d i a z e n y l] q u i n o l i n-8-o l$ [6]. The chemistry and structural properties of organotin(IV) 5-[(E)-2-(aryl)-1-diazenyl]quinolinolate(s) have also been explored for mixed ligand complexes which provided some elegant structural architectures [6] (see scheme 1 (ii-viii)). The literature contains no reports of structural characterization by X-ray crystallography of dimethyltin(IV) compounds with 5-[(E)-2-(aryl)-1-diazenyl]quinolinolate(s), except for a very old report involving the ligand precursor quinolin-8-ol (Ox), i.e. $\mathrm{Me}_{2} \mathrm{SnO}_{2}$ [7], which had been characterized because of conflicting structural conclusions (octahedral coordination with the possibility of either a cis- or trans- methyl group) obtained from both NMR, IR and ${ }^{119}$ Sn Mössbauer results.

The present paper reports the results of extending the organotin(IV) work, particularly the combination of $\mathrm{Me}_{2} \mathrm{Sn}$ with bulkier 5-[(E)-2-(aryl)-1-diazenyl]quinolin-8-ols (aryl = 4'-methylphenyl- $\quad\left(\mathrm{L}^{1} \mathrm{H}\right), \quad$ 4'-methoxyphenyl- $\quad\left(\mathrm{L}^{2} \mathrm{H}\right), \quad$ 4'-ethoxyphenyl- $\left(\mathrm{L}^{3} \mathrm{H}\right) \quad$ and 4'-bromophenyl- $\left(\mathrm{L}^{4} \mathrm{H}\right)$; refer to scheme 1 (i) for ligand description). The aim of the study was to evaluate the bonding mode(s) and to judge the disposition of the Sn-Me groups in $\mathrm{Me}_{2} \mathrm{Sn}(\mathrm{L})_{2}$ and $\mathrm{Me}_{2} \mathrm{SnCl}(\mathrm{L})$ complexes from a detailed analysis of their IR, NMR $\left({ }^{1} \mathrm{H},{ }^{13} \mathrm{C},{ }^{119} \mathrm{Sn}\right)$ and ${ }^{119} \mathrm{Sn}$ Mössbauer spectroscopic studies. Further, in the course of the studies in this area, the dimethyltin(IV) complex $\mathrm{Me}_{2} \mathrm{Sn}\left(\mathrm{L}^{2}\right)_{2}$ (2) and a chloro derivative $\mathrm{Me}_{2} \mathrm{SnCl}\left(\mathrm{L}^{3}\right)$ (6) (as its toluene solvate) provided X-ray quality crystals enabling a detailed analysis of the coordination geometry and the supramolecular structures of these materials.

\section{Experimental}

\subsection{Materials}

$\mathrm{Me}_{2} \mathrm{SnCl}_{2}$ (Aldrich), Oxine (Merck) and the substituted anilines (reagent grade) were used without purification. The solvents used in the reactions were AR grade and dried using standard procedures. Benzene was distilled from sodium benzophenone ketyl. The ligands, viz., 5-[(E)-2(4-methylphenyl)-1-diazenyl]quinolin-8-ol $\quad\left(\mathrm{L}^{1} \mathrm{H}\right), \quad$ 5-[(E)-2-(4-methoxyphenyl)-1diazenyl]quinolin-8-ol $\left(\mathrm{L}^{2} \mathrm{H}\right), \quad 5-[(E)-2-(4-e t h o x y p h e n y l)-1-d i a z e n y l] q u i n o l i n-8-o l ~\left(\mathrm{~L}^{3} \mathrm{H}\right)$ and 5-[(E)-2-(4-bromophenyl)-1-diazenyl]quinolin-8-ol $\left(\mathrm{L}^{4} \mathrm{H}\right)$ were synthesized by following previously described procedures $[1,2]$. 


\subsection{Physical measurements}

Carbon, hydrogen and nitrogen analyses were performed with a Perkin-Elmer 2400 series II instrument. IR spectra $\left(4000-400 \mathrm{~cm}^{-1}\right)$ were obtained on a BOMEM DA-8 FT-IR spectrophotometer as KBr discs. ${ }^{1} \mathrm{H},{ }^{13} \mathrm{C}$ and ${ }^{119} \mathrm{Sn}-\mathrm{NMR}$ spectra of the complexes were recorded on a Bruker AMX 400 spectrometer and measured at 400.13, 100.62 and $149.18 \mathrm{MHz}$,

respectively. The ${ }^{1} \mathrm{H},{ }^{13} \mathrm{C}$ and ${ }^{119} \mathrm{Sn}$ chemical shifts were referred to $\mathrm{Me}_{4} \mathrm{Si}$ set at $0.00 \mathrm{ppm}$, $\mathrm{CDCl}_{3}$ set at $77.0 \mathrm{ppm}$ and $\mathrm{Me}_{4} \mathrm{Sn}$ set at $0.00 \mathrm{ppm}$, respectively. Mössbauer spectra of the complexes in the solid-state were recorded using a Ranger Model MS-900 spectrometer in the acceleration mode with a moving source geometry. A $5 \mathrm{mCi} \mathrm{Ca}{ }^{119} \mathrm{SnO}_{3}$ source was used, and counts of 30000 or more accumulated for each spectrum. The spectra were measured at $80 \mathrm{~K}$ using a liquid-nitrogen cryostat. The velocity was calibrated at ambient temperature using a composition of $\mathrm{BaSnO}_{3}$ and tin foil (splitting $2.52 \mathrm{~mm} \mathrm{~s}^{-1}$ ). The resultant spectra were analyzed using the software package from Web research corporation.

\subsection{Synthesis of dimethyltin(IV) complexes}

2.3.1. Synthesis of $\mathrm{Me}_{2} \operatorname{Sn}\left(\mathbf{L}^{1}\right)_{2}(1)$. A methanolic solution of sodium methoxide (generated in situ from $0.044 \mathrm{~g}, 1.90 \mathrm{mmol}$ of $\mathrm{Na}$ in anhydrous methanol) was added dropwise into a stirred hot anhydrous benzene solution $(45 \mathrm{ml})$ containing $\mathrm{L}^{1} \mathrm{H}(0.5 \mathrm{~g}, 1.90 \mathrm{mmol})$. After complete addition, a precipitate appears and the stirring was continued for $15 \mathrm{~min}$. To this reaction mixture, an anhydrous benzene solution $(15 \mathrm{ml})$ of $\mathrm{Me}_{2} \mathrm{SnCl}_{2}(0.20 \mathrm{~g}, 0.91 \mathrm{mmol})$ was added dropwise which resulted in the disappearance of the precipitate. The reaction mixture was refluxed for $3 \mathrm{~h}$ and filtered to remove $\mathrm{NaCl}$. The filtrate was collected and the solvent was removed under reduced pressure. The residue was washed with hexane and dried in vacuo. The dried residue was dissolved in benzene, precipitated with hexane, filtered and dried. The crude product was crystallized from a mixture of benzene and hexane (v/v, 1:1) to afford orange crystals. Yield: $0.35 \mathrm{~g}$ (57\%), m.p.: 200-201 ${ }^{\circ} \mathrm{C}$. Anal. Calcd. for $\mathrm{C}_{34} \mathrm{H}_{30} \mathrm{~N}_{6} \mathrm{O}_{2} \mathrm{Sn}(\%)$ : C, 60.65; H, 4.49; N, 12.48. Found: C, 61.05; H, 4.29; N, 12.32. IR $\left(\mathrm{cm}^{-1}\right): 1248 v(\mathrm{C}(\operatorname{aryl}) \mathrm{O}) .{ }^{1} \mathrm{H}$ NMR $\left(\mathrm{CDCl}_{3}\right) ; \delta_{\mathrm{H}}: 9.28$ [dd, 2H, H4], 8.56 [dd, 2H, H2], 8.21 [d, 2H, H6], 7.82 [m, 4H, H2' \& H6'], 7.20-7.42 [m, 8H, H3, H7, H3' \& H5'], 2.44 [s, 6H, CH $3,0.55\left[\mathrm{~s}, 6 \mathrm{H}, \mathrm{Sn}-\mathrm{CH}_{3},{ }^{2} J\left({ }^{119} \mathrm{Sn},{ }^{1} \mathrm{H}=69\right.\right.$ $\mathrm{Hz})$, ppm. ${ }^{13} \mathrm{C}$ NMR $\left(\mathrm{CDCl}_{3}\right) ; \delta_{\mathrm{C}}: 161.3$ [C8], 151.5 [C1'], 142.8 [C2], 140.5 [C4'], 136.4 [C5], 135.7 [C4], 135.3 [C8a], 129.7 [C3' \& C5'], 128.7 [C4a], 122.5 [C2' \& C6'], 122.4 [C3], 118.5 
[C6], 114.1 [C7], $21.4\left[\mathrm{CH}_{3}\right], 7.30\left[\mathrm{Sn}-\mathrm{CH}_{3},{ }^{1} J\left({ }^{119} \mathrm{Sn},{ }^{13} \mathrm{C}=625 \mathrm{~Hz}\right)\right], \mathrm{ppm} .{ }^{119} \mathrm{Sn}$ NMR $\left(\mathrm{CDCl}_{3}\right)$ $\delta_{\mathrm{Sn}}:-224.0$ ppm. ${ }^{119}$ Sn Mössbauer: $\delta=0.86, \Delta=2.06, \Gamma_{1}=1.09, \Gamma_{2}=1.14 \mathrm{~mm} \mathrm{~s}^{-1}$.

The other dimethyltin(IV) complexes were prepared by reacting appropriate ligands, $\mathrm{L}^{2} \mathrm{H}-\mathrm{L}{ }^{4} \mathrm{H}$ with $\mathrm{Me}_{2} \mathrm{SnCl}_{2}$ by following the above procedure. The characterization and spectroscopic data of the complexes are presented below.

2.3.2. Synthesis of $\mathrm{Me}_{2} \mathrm{Sn}\left(\mathrm{L}^{2}\right)_{2}$ (2). Red crystals of 2 were obtained from a mixture of benzene and hexane (v/v, 1:1). Yield: 65\%, m.p.: 218-219 ${ }^{\circ} \mathrm{C}$. Anal. Calcd. for $\mathrm{C}_{34} \mathrm{H}_{30} \mathrm{~N}_{6} \mathrm{O}_{4} \mathrm{Sn}(\%)$ : C, 57.90; H, 4.29; N, 11.91. Found: C, 57.78; H, 4.53; N, 11.88. IR $\left(\mathrm{cm}^{-1}\right): 1255 v(\mathrm{C}(\operatorname{aryl}) \mathrm{O})$. ${ }^{1} \mathrm{H}$ NMR $\left(\mathrm{CDCl}_{3}\right) ; \delta_{\mathrm{H}}: 9.27$ [dd, 2H, H4], 8.56 [dd, 2H, H2], 8.18 [d, 2H, H6], 7.89 [m, 4H, H2' \& H6'], 7.20-7.40 [m, 4H, H3 \& H7], 7.01 [m, 4H, H3' \& H5'], 3.85 [s, 6H, $\mathrm{OCH}_{3}$ ], 0.50 [s, 6H, $\mathrm{Sn}-\mathrm{CH}_{3},{ }^{2} J\left({ }^{119} \mathrm{Sn},{ }^{1} \mathrm{H}=70 \mathrm{~Hz}\right)$ ], ppm. ${ }^{13} \mathrm{C}$ NMR $\left(\mathrm{CDCl}_{3}\right) ; \delta_{\mathrm{C}}: 161.4$ [C8], 160.8 [C1'], 147.8 [C4'], 142.8 [C2], 136.4 [C5], 135.6 [C4], 135.3 [C8a], 128.5 [C4a], 124.2 [C3'\& C5'], 122.2 [C3], 118.1 [C6], 114.2 [C2'\& C6'], 114.1 [C7], $55.5\left[\mathrm{OCH}_{3}\right], 7.30\left[\mathrm{Sn}^{\prime} \mathrm{CH}_{3},{ }^{1} J\left({ }^{119} \mathrm{Sn},{ }^{13} \mathrm{C}=\right.\right.$ $625 \mathrm{~Hz})]$, ppm. ${ }^{119} \mathrm{Sn}$ NMR $\left(\mathrm{CDCl}_{3}\right) \delta_{\mathrm{Sn}}$ : $-224.6 \mathrm{ppm} .{ }^{119} \mathrm{Sn}$ Mössbauer: $\delta=0.86, \Delta=2.05, \Gamma_{1}=$ $1.14, \Gamma_{2}=1.21 \mathrm{~mm} \mathrm{~s}^{-1}$.

2.3.3. $\mathrm{Me}_{2} \operatorname{Sn}\left(\mathbf{L}^{3}\right)_{2}(3)$. Orange crystals of 3 were obtained from a mixture of benzene and hexane (v/v, 1:1). Yield: 68\%, m.p.: 196-197 ${ }^{\circ} \mathrm{C}$. Anal. Calcd. for $\mathrm{C}_{36} \mathrm{H}_{34} \mathrm{~N}_{6} \mathrm{O}_{4} \mathrm{Sn}(\%)$ : C, 58.96; H, 4.67; $\mathrm{N}, 11.46$. Found: $\mathrm{C}, 58.63 ; \mathrm{H}, 4.66 ; \mathrm{N}, 11.54 . \mathrm{IR}\left(\mathrm{cm}^{-1}\right): 1255 \mathrm{v}(\mathrm{C}(\operatorname{aryl}) \mathrm{O}) .{ }^{1} \mathrm{H}$ NMR $\left(\mathrm{CDCl}_{3}\right)$; $\delta_{\mathrm{H}}: 9.25$ [dd, 2H, H4], 8.55 [dd, 2H, H2], 8.17 [d, 2H, H6], 7.90 [m, 4H, H2' \& H6'], 7.22-7.40 [m, 4H, H3 \& H7], 7.0 [d, 4H, H3' \& H5'], 4.13 [q, 4H, OCH $\mathrm{CH}_{3}$ ], 1.45 [t, 6H, $\mathrm{OCH}_{2} \mathrm{CH}_{3}$ ], 0.54 [s, 6H, Sn-CH $\left.3,{ }^{2} J\left({ }^{119} \mathrm{Sn},{ }^{1} \mathrm{H}=70 \mathrm{~Hz}\right)\right]$, ppm. ${ }^{13} \mathrm{C} \mathrm{NMR}\left(\mathrm{CDCl}_{3}\right) ; \delta_{\mathrm{C}}: 160.8$ [C8 \& C1'], 147.6 [C4'], 142.8 [C2], 136.4 [C5], 135.6 [C4], 135.3 [C8a], 128.5 [C4a], 124.2 [C3' \& C5'], 122.1 [C3], 118.1 [C6], 114.7 [C2' \& C6'], 114.0 [C7], $63.8\left[\mathrm{OCH}_{2} \mathrm{CH}_{3}\right], 14.8\left[\mathrm{OCH}_{2} \mathrm{CH}_{3}\right], 7.20$ $\left[\mathrm{Sn}-\mathrm{CH}_{3},{ }^{1} J\left({ }^{119} \mathrm{Sn},{ }^{13} \mathrm{C}=625 \mathrm{~Hz}\right)\right]$, ppm. ${ }^{119} \mathrm{Sn} \mathrm{NMR}\left(\mathrm{CDCl}_{3}\right) \delta_{\mathrm{Sn}}:-224.7 \mathrm{ppm} .{ }^{119} \mathrm{Sn}$ Mössbauer: $\delta=0.88, \Delta=2.22, \Gamma_{1}=1.01, \Gamma_{2}=1.06 \mathrm{~mm} \mathrm{~s}^{-1}$.

2.3.4. $\mathrm{Me}_{2} \operatorname{Sn}\left(\mathrm{L}^{4}\right)_{2}$ (4). Orange crystals of 4 were obtained from a mixture of benzene and hexane (v/v, 1:1). Yield: 73\%, m.p.: 208-209 ${ }^{\circ} \mathrm{C}$. Anal. Calcd. for $\mathrm{C}_{32} \mathrm{H}_{24} \mathrm{~N}_{6} \mathrm{O}_{2} \mathrm{Br} 2 \mathrm{Sn}(\%)$ : C, 47.85; H, 3.01; N, 10.46. Found: C, 47.70; H, 2.89; N, 10.66. IR $\left(\mathrm{cm}^{-1}\right): 1248$ v(C(aryl)O). ${ }^{1} \mathrm{H}$ NMR 
$\left(\mathrm{CDCl}_{3}\right) ; \delta_{\mathrm{H}}: 9.27$ [dd, 2H, H4], 8.55 [dd, 2H, H2], 8.27 [d, 2H, H6], 7.78 [m, 4H, H2' \& H6'], 7.63 [m, 4H, H3' \& H5'], 7.38 [m, 4H, H3 \& H7], 0.57 [s, 6H, Sn- $\left.\mathrm{CH}_{3},{ }^{2} J\left({ }^{119} \mathrm{Sn},{ }^{1} \mathrm{H}=69 \mathrm{~Hz}\right)\right]$, ppm. ${ }^{13} \mathrm{C} \mathrm{NMR}\left(\mathrm{CDCl}_{3}\right) ; \delta_{\mathrm{C}}: 161.9$ [C8], 152.1 [C1'], 142.9 [C2], 136.2 [C4], 135.6 [C5], 135.3 [C8a], 132.3 [C3' \& C5'], 128.9 [C4a], 123.9 [C2' \& C6'], 122.6 [C3], 119.1 [C6], 114.2 [C7], ppm. C4' could not be detected, possibly overlapped with other signals. ${ }^{119} \mathrm{Sn}$ NMR $\left(\mathrm{CDCl}_{3}\right) \delta_{\mathrm{Sn}}$ : -222.0 ppm. ${ }^{119}$ Sn Mössbauer: $\delta=0.87, \Delta=2.17, \Gamma_{1}=1.16, \Gamma_{2}=1.39 \mathrm{~mm} \mathrm{~s}^{-1}$.

2.3.5. $\mathrm{Me}_{2} \mathrm{SnCl}\left(\mathrm{L}^{2}\right)$ (5). A methanolic solution of sodium methoxide (generated in situ from $0.04 \mathrm{~g}, 1.74 \mathrm{mmol}$ of $\mathrm{Na}$ in anhydrous methanol) was added dropwise into a stirred hot anhydrous benzene solution $(45 \mathrm{ml})$ containing $\mathrm{L}^{2} \mathrm{H}(0.5 \mathrm{~g}, 1.79 \mathrm{mmol})$. After complete addition, a precipitate appears and the stirring was continued for $15 \mathrm{~min}$. To this reaction mixture, an anhydrous benzene solution $(15 \mathrm{ml})$ of $\mathrm{Me}_{2} \mathrm{SnCl}_{2}(0.39 \mathrm{~g}, 1.79 \mathrm{mmol})$ was added dropwise which resulted in the disappearance of the precipitate. The reaction mixture was refluxed for $3 \mathrm{~h}$ and filtered to remove $\mathrm{NaCl}$. The filtrate was collected and the solvent was removed under reduced pressure. The resultant residue was washed with hexane and dried in vacuo. The dried residue was dissolved in benzene, precipitated with hexane, filtered and dried. Orange crystals of 5 were obtained from a mixture of benzene and hexane (v/v, 1:1). Yield: $0.38 \mathrm{~g}$ (46\%), m.p.: 160-161 ${ }^{\circ} \mathrm{C}$. Anal. Calcd. for $\mathrm{C}_{18} \mathrm{H}_{18} \mathrm{~N}_{3} \mathrm{O}_{2} \mathrm{SnCl}(\%)$ : C, 46.74; H, 3.92; N, 9.08. Found: C, 46.72; $\mathrm{H}, 3.91 ; \mathrm{N}, 9.35$. IR $\left(\mathrm{cm}^{-1}\right): 1259 \mathrm{~V}(\mathrm{C}(\operatorname{aryl}) \mathrm{O}) .{ }^{1} \mathrm{H}$ NMR $\left(\mathrm{CDCl}_{3}\right) ; \delta_{\mathrm{H}}: 9.65$ [dd, $\left.1 \mathrm{H}, \mathrm{H} 4\right], 8.20$ [dd, 1H, H2], 7.95 [m, 2H, H2 \& H6'], 7.80 [m, 1H, H6], 7.20-7.40 [m, 2H, H3 \& H7], 7.00 [m,

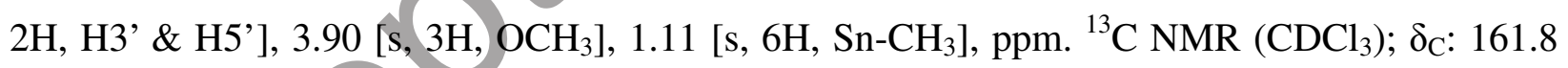
[C8], 160.0 [C1'], 147.6 [C4'], 145.3 [C2], 142.8 [C5], 138.2 [C4], 135.6 [C8a], 128.3 [C4a], 124.5 [C3' \& C5'], 122.4 [C3], 118.3 [C6], 115.1 [C7], 114.3 [C2'\& C6'], 55.6 [OCH 3 ], 7.90 $\left[\mathrm{Sn}-\mathrm{CH}_{3},{ }^{1} \mathrm{~J}\left({ }^{19} \mathrm{Sn},{ }^{13} \mathrm{C}=640 \mathrm{~Hz}\right)\right]$, ppm. ${ }^{119} \mathrm{Sn} \mathrm{NMR}\left(\mathrm{CDCl}_{3}\right) \delta_{\mathrm{Sn}}:-83.5 \mathrm{ppm} .{ }^{119} \mathrm{Sn}$ Mössbauer: $\delta=1.12, \Delta=2.80, \Gamma_{1}=1.36, \Gamma_{2}=1.52 \mathrm{~mm} \mathrm{~s}^{-1}$.

2.3.6. $\mathrm{Me}_{2} \mathrm{SnCl}\left(\mathrm{L}^{3}\right) \cdot \mathrm{C}_{7} \mathrm{H}_{8}(6)$. Orange crystals of 6 were obtained from a mixture of toluene and chloroform (v/v, 1:1). Yield: 49\%, m.p.: $135-136{ }^{\circ} \mathrm{C}$. Anal. Calcd. for $\mathrm{C}_{26} \mathrm{H}_{28} \mathrm{ClN}_{3} \mathrm{O}_{2} \mathrm{Sn}(\%)$ : C, 54.89; H, 4.96; N, 7.39. Found: C, 55.10; H, 4.90; N, 7.62. IR $\left(\mathrm{cm}^{-1}\right): 1257 \mathrm{v}(\mathrm{C}(\operatorname{aryl}) \mathrm{O})$. ${ }^{1} \mathrm{H}$ NMR $\left(\mathrm{CDCl}_{3}\right) ; \delta_{\mathrm{H}}: 9.65$ [dd, 1H, H4], 9.10 [dd, 1H, H2], 8.20 [d, 1H, H6], 8.0 [m, 2H, H2' \& H6'], 7.80 [m, 1H, H3], 7.30 [d, 1H, H7], 7.05 [d, 2H, H3' \& H5'], 4.14 [q, 2H, $\mathrm{OCH}_{2} \mathrm{CH}_{3}$ ], 
$1.49\left[\mathrm{t}, 3 \mathrm{H}, \mathrm{OCH}_{2} \mathrm{CH}_{3}\right], 1.11$ [s, $\left.6 \mathrm{H}, \mathrm{Sn}-\mathrm{CH}_{3}\right], \mathrm{ppm} .{ }^{13} \mathrm{C} \mathrm{NMR}\left(\mathrm{CDCl}_{3}\right) ; \delta_{\mathrm{C}}: 161.2$ [C8], 159.9 [C1'], 147.5 [C4'], 145.3 [C2], 138.2 [C5], 136.6 [C4], 136.2 [C8a], 128.3 [C4a], 124.5 [C3'\& C5'], 122.3 [C3], 118.2 [C6], 115.1 [C7], 114.8 [C2' \& C6'], 63.8 [ $\left.\mathrm{OCH}_{2} \mathrm{CH}_{3}\right], 14.7$ $\left[\mathrm{OCH}_{2} \mathrm{CH}_{3}\right], 7.90\left[\mathrm{Sn}-\mathrm{CH}_{3},{ }^{1} J\left({ }^{119} \mathrm{Sn},{ }^{13} \mathrm{C}=620 \mathrm{~Hz}\right)\right]$, ppm. ${ }^{119} \mathrm{Sn} \mathrm{NMR}\left(\mathrm{CDCl}_{3}\right) \delta_{\mathrm{Sn}}:-84.5 \mathrm{ppm}$. ${ }^{119}$ Sn Mössbauer: $\delta=1.11, \Delta=2.84, \Gamma_{1}=1.33, \Gamma_{2}=1.56 \mathrm{~mm} \mathrm{~s}^{-1}$.

\subsection{X-ray crystallography}

Crystals of $\mathbf{2}$ and $\mathbf{6}$ suitable for an X-ray crystal-structure determination were obtained from slow evaporation of benzene/hexane and toluene/chloroform ( $\mathrm{v} / \mathrm{v}$ 1:1) solutions of the respective compounds. All measurements were made at $160 \mathrm{~K}$ on a Nonius KappaCCD diffractometer [8] with graphite-monochromated Mo K $\alpha$ radiation $(\lambda=0.71073 \AA)$ and an Oxford Cryosystems Cryostream 700 cooler. Data reduction was performed with HKL Denzo and Scalepack [9]. The intensities were corrected for Lorentz and polarization effects and empirical absorption corrections based on the multi-scan method [10] were applied. Equivalent reflections were merged. The data collection and refinement parameters are given in table 1, and views of $\mathbf{2}$ and $\mathbf{6}$ are shown in figures 1 and 2. The structures for $\mathbf{2}$ and $\mathbf{6}$ were solved by direct-methods using SIR92 [11].

In 6, the asymmetric unit contains one molecule of the Sn complex plus one disordered toluene. Two sets of slightly different positions were defined for the atoms of toluene and the site occupation factor of the major orientation of the molecule refined to 0.597(5). Similarity restraints were applied to all chemically equivalent bond lengths and angles involving the disordered carbons, while neighboring atoms within and between each orientation of the disordered toluene molecule were restrained to have similar atomic displacement parameters.

The non-hydrogen atoms were refined anisotropically. All hydrogens were placed in geometrically calculated positions and refined by using a riding model where each $\mathrm{H}$ was assigned a fixed isotropic displacement parameter with a value equal to $1.2 U_{\text {eq }}$ of its parent $\mathrm{C}$ $\left(1.5 U_{\text {eq }}\right.$ for methyls). The refinement of each structure was carried out on $F^{2}$ using full-matrix least-squares procedures, which minimize the function $\Sigma w\left(F_{\mathrm{o}}{ }^{2}-F_{\mathrm{c}}{ }^{2}\right)^{2}$. Corrections for secondary extinction were applied. Four reflections in $\mathbf{6}$, whose intensities were considered to be extreme outliers, were omitted from the final refinement. All calculations were performed using the SHELXL97 program [12]. 


\section{Results and discussion}

\subsection{Synthesis}

Dimethyltin(IV) complexes of the 5-[(E)-2-(aryl)-1-diazenyl)quinolin-8-ol (LH) could be prepared by reacting stoichiometric amounts of $\mathrm{Me}_{2} \mathrm{SnCl}_{2}$ and $\mathrm{LNa}$ (generated in situ from $\mathrm{Na}$ and anhydrous methanol) in anhydrous benzene (Eqns. 1 and 2).

$$
\begin{aligned}
& 2 \mathrm{LH}+2 \mathrm{NaOMe}+\mathrm{Me}_{2} \mathrm{SnCl}_{2} \underset{\text { Reflux, } 3 \mathrm{~h}}{\stackrel{\text { Benzene }}{\longrightarrow}} \mathrm{Bz} 2 \mathrm{Sn}(\mathrm{L})_{2}+2 \mathrm{MeOH}+2 \mathrm{NaCl} \\
& \mathrm{LH}+\mathrm{NaOMe}+\mathrm{Me}_{2} \mathrm{SnCl}_{2} \underset{\text { Reflux, } 3 \mathrm{~h}}{\stackrel{\text { Benzene }}{\longrightarrow}} \mathrm{Me}_{2} \mathrm{SnCl}(\mathrm{L})+\mathrm{MeOH}+\mathrm{NaCl}
\end{aligned}
$$

These reactions proceeded smoothly and pure products were obtained in yields $>45 \%$. The work-up details and characterization data for the complexes are described in section 2.3. The complexes are air stable and soluble in all common organic solvents.

\subsection{IR and NMR $\left({ }^{1} \mathrm{H},{ }^{13} \mathrm{C}\right.$ and $\left.{ }^{119} \mathrm{Sn}\right)$ data}

The $v(\mathrm{OH})$ of $\mathrm{L}^{1} \mathrm{H}-\mathrm{L}^{4} \mathrm{H}$ at $\sim 3380 \mathrm{~cm}^{-1}$ are absent in the dimethyltin(IV) complexes, 1-6, confirming bonding through oxygen of the ligand. A strong band around $1235 \mathrm{~cm}^{-1}$ due to $v(\mathrm{C}(\operatorname{aryl})-\mathrm{O})$ (i.e. $\left.\mathrm{C}_{8}-\mathrm{O}\right)$ in the ligands shifts to $\sim 1250 \mathrm{~cm}^{-1}$ in the complexes, which is in agreement with our earlier observation of $\mathrm{O} \rightarrow \mathrm{Sn}$ connection [1-5]. There are many absorptions in the 500-600 $\mathrm{cm}^{-1}$ region, so no assignments to the $v(\mathrm{Sn}-\mathrm{C})$ modes are possible for 1-6.

The ${ }^{1} \mathrm{H}$ and ${ }^{13} \mathrm{C}$ NMR signals for the $\mathrm{L}^{1} \mathrm{H}-\mathrm{L}{ }^{4} \mathrm{H}$ were assigned by the use of correlated spectroscopy (COSY), heteronuclear single-quantum correlation (HSQC) and heteronuclear multiple-bond connectivities (HMBC) experiments [1, 2]. The conclusions drawn from the ligand assignments were then extrapolated to 1-6 owing to the data similarity. The ${ }^{1} \mathrm{H}$ NMR integration values were consistent with the formulation of the products. The ${ }^{1} \mathrm{H}$ and ${ }^{13} \mathrm{C} \mathrm{NMR}$ chemical shift assignments for the dimethyltin(IV) are straightforward using the multiplicity pattern and also by examining the ${ }^{1} J\left({ }^{13} \mathrm{C}-{ }^{119 / 117} \mathrm{Sn}\right)$ coupling constants $[13,14]$. In the ${ }^{1} \mathrm{H}$ and ${ }^{13} \mathrm{C}$ NMR spectra of 1-6 there is only one set of NMR signals for both the methyl groups 
(Sn-Me), which provides evidence for magnetic equivalence of both methyls on the NMR time scale, indicating their symmetrical arrangement in the coordination sphere of tin in solution. The chemical shifts $\delta\left({ }^{1} \mathrm{H}\right)$ and $\delta\left({ }^{13} \mathrm{C}\right)$ of Sn-R are not very sensitive to changes in coordination of tin. The coupling constants due to Sn-R: ${ }^{2} J\left({ }^{119} \mathrm{Sn},{ }^{1} \mathrm{H}\right)=70 \mathrm{~Hz}$ and ${ }^{1} J\left({ }^{119} \mathrm{Sn},{ }^{13} \mathrm{C}\right)=630 \mathrm{~Hz}$ of 1-4 match (see experimental section) closely with data for six-coordinate $\left[\mathrm{Me}_{2} \mathrm{Sn}(\mathrm{Ox})_{2}\right][13,15]$ in $\mathrm{CDCl}_{3}$ solution. Similarly, ${ }^{1} J\left({ }^{119} \mathrm{Sn},{ }^{13} \mathrm{C}\right)=645 \mathrm{~Hz}$ of 5 and $\mathbf{6}$ match that observed for $\left[\mathrm{Me}_{2} \mathrm{SnCl}(\mathrm{Ox})\right][16]$. Further structural conclusions have been extracted from ${ }^{119} \mathrm{Sn}$ solution NMR spectra. Complexes 1-4 display a sharp singlet at $-224 \mathrm{ppm}$, suggesting that Sn are isostructural in solution and the values match well with those reported for six-coordinate $\left[\mathrm{Me}_{2} \mathrm{Sn}(\mathrm{Ox})_{2}\right]=-237 \mathrm{ppm}$ [17] and cognate cis-bis $\{5-[(E)-2$-(2-carbomethoxyphenyl)-1diazenyl]quinolinolato dimethyltin(IV) [4] in $\mathrm{CDCl}_{3}$ solution. Complexes 5 and $\mathbf{6}$ display a sharp singlet at $-84 \mathrm{ppm}$ and the values correlate well with those reported for five-coordinate $\left[\mathrm{Me}_{2} \mathrm{SnCl}(\mathrm{Ox})\right]=-92 \mathrm{ppm}$ in $\mathrm{CHCl}_{3}$ solution [17].

\section{3. ${ }^{119}$ Sn Mössbauer data}

${ }^{119} \mathrm{Sn}$ Mössbauer data can usually give information on the covalency of bonds formed by tin through determination of the isomer shift values, $\delta$, and also insight into the probable structures of the complexes, in solid state or frozen solution, by determination of experimental nuclear quadrupole splittings, $\left|\Delta_{\exp }\right|$. The dimethyltin(IV) complexes 1-4 display $\delta$ values of 0.86$0.88 \mathrm{~mm} \mathrm{~s}^{-1}$, which are typical of diorganotin(IV) derivatives [18] and fall within the limits of $\delta$ values observed for related diorganotin(IV) quinolinolates: $\left[\mathrm{Me}_{2} \mathrm{Sn}(\mathrm{Ox})_{2}\right]=0.88 \mathrm{~mm} \mathrm{~s}^{-1}$ [19]; cis-bis $\left\{5-[(E)-2\right.$-(phenyl)-1-diazenyl]quinolinolato $\}$ dimethyltin(IV) $=0.93 \mathrm{~mm} \mathrm{~s}^{-1}[20]$ and cis$\operatorname{bis}\left\{5-[(E)-2-(2\right.$-carbomethoxyphenyl)-1-diazenyl $]$ quinolinolato $\}$ dimethyltin(IV) $=0.84 \mathrm{~mm} \mathrm{~s}^{-1}$ [4]. The measured quadrupole splitting values $\left|\Delta_{\text {exp }}\right|$ of $2.05-2.22 \mathrm{~mm} \mathrm{~s}^{-1}$ are consistent with cis $-\mathrm{R}_{2}$ octahedral structures which characterize 1-4, albeit as severely distorted octahedral $[21,22]$. Further, $\left|\Delta_{\text {exp }}\right|$ values for $\mathbf{1 - 4}$ compare well with data for related $\left[\mathrm{Me}_{2} \operatorname{Sn}(\mathrm{Ox})_{2}\right]=$ $1.98 \mathrm{~mm} \mathrm{~s}^{-1}$ [19] having a cis- $\mathrm{Me}_{2} \mathrm{Sn}$ octahedral geometry as confirmed by single crystal X-ray crystallography [7] and also match with data reported for cis-bis\{5-[(E)-2-(phenyl)-1diazenyl]quinolinolato $\}$ dimethyltin(IV) $=2.18 \mathrm{~mm} \mathrm{~s}^{-1}[20]$ and cis-bis $\{5-[(E)-2-(2-$ carbomethoxyphenyl)-1-diazenyl]quinolinolato dimethyltin(IV) $=2.04 \mathrm{~mm} \mathrm{~s}^{-1}$ [4]. The similar magnitudes of $\delta$ and $\left|\Delta_{\text {exp }}\right|$ values in 1-4 further indicate that the complexes are isostructural. On 
the other hand, 5 and 6 exhibit $\left|\Delta_{\text {exp }}\right|$ values of approximately $2.80 \mathrm{~mm} \mathrm{~s}^{-1}$ and the values are higher than that of the dibutyltin(IV) analogue ${ }^{n} \mathrm{Bu}_{2} \mathrm{SnCl}(\mathrm{L})=2.51 \mathrm{~mm} \mathrm{~s}^{-1}(\mathrm{~L}=5-[(E)-2-(4-$ methoxyphenyl)-1-diazenyl]quinolinolate) [3] which has a cis-trigonal bipyramidal geometry as characterized by crystallography [6]. Moreover, $\left|\Delta_{\exp }\right|$ values of 5 and $\mathbf{6}$ are lower compared to $\left[\mathrm{Me}_{2} \mathrm{SnCl}(\mathrm{Ox})\right]=3.12 \mathrm{~mm} \mathrm{~s}^{-1}$ [23] which has the same formulation and a cis-trigonal bipyramidal geometry was proposed [23] with tentative placement of atoms in axial and equatorial positions in the absence of diffraction data. Thus, Mössbauer spectroscopic data suggest a cis- $\mathrm{R}_{2} \mathrm{Sn}$ octahedral geometry for $\mathbf{1 - 4}$, where the four positions in one plane are defined by two oxygens, a nitrogen and an organo group, while the two sites perpendicular to that are occupied by an organo group and a nitrogen. A distorted cis-trigonal bipyramidal geometry is indicated for $\mathbf{5}$ and $\mathbf{6}$, where the bidentate quinolin-8-olate ligand coordinates such that the $\mathrm{N}$ and $\mathrm{O}$ are in axial and equatorial positions, respectively. The other axial position is occupied by $\mathrm{Cl}^{-}$ and the methyl groups complete the equatorial plane. The structures of two representative complexes, $\mathbf{2}$ and $\mathbf{6}$, have been confirmed from diffraction study (see below).

\subsection{Structural results from single crystal $X$-ray diffraction}

The results of the X-ray crystallographic study on $\mathbf{2}$ and $\mathbf{6}$ (figures 1 and 2) are consistent with spectroscopic evidence described in sections 3.2-3.3. The selected geometric parameters of 2 and $\mathbf{6}$ are given in tables 2 and 3 , respectively.

$\mathrm{Sn}$ in $\mathbf{2}$ has a distorted octahedral coordination geometry in which oxygens from the two bidentate ligands are approximately trans, while the quinolin-8-olate nitrogens are trans to methyls. The small bite angle subtended by the donors of the quinolin-8-olate moiety is the main reason for distortion from regular octahedral geometry, as observed for its dibutyltin(IV), diphenyltin(IV) and dibenzyltin(IV) analogues [1-4]. The metric parameters of 2 compare well with those of their diorganotin(IV) analogues and the Sn-coordination geometry is also very similar [1-4]. There are ten diorganotin bis(quinolin-8-olate) structures bearing similar azo functionality available in the literature for comparison [1-3], e.g., $\mathrm{Bu}_{2} \mathrm{SnL}_{2}: \mathrm{R}=4^{\prime}-\mathrm{CH}_{3} ; \mathrm{R}=$ 4'- $\mathrm{OCH}_{3} ; \mathrm{R}=4^{\prime}-\mathrm{OC}_{2} \mathrm{H}_{5} ; \mathrm{R}=4^{\prime}-\mathrm{Br}$ [3], $\mathrm{Ph}_{2} \mathrm{SnL}_{2}: \mathrm{R}=\mathrm{H} ; \mathrm{R}=4{ }^{\prime}-\mathrm{CH}_{3} ; \mathrm{R}=4$ '- $\mathrm{Br}$ [2], $\mathrm{Bz}_{2} \mathrm{SnL}_{2}: \mathrm{R}=$ 4'- $\mathrm{CH}_{3} ; \mathrm{R}=4{ }^{\prime}-\mathrm{OCH}_{3} ; \mathrm{R}=4$ '- $\mathrm{Br}$ [1] (see scheme 1(i) for details). One of the quinolin-8-olate ligands in $\mathbf{2}$ is quite planar, while the other has a significant twist of the plane of the terminal methoxyphenyl segment out of the plane of the fused rings of the ligand. The dihedral angle 
between these planes is about $47^{\circ}$. This difference in planarity is correlated with the observed packing of the molecules. The molecules are arranged so that the planar quinolin-8-olates align face-to-face to give columns of parallel ligands interpenetrating from molecules lying on opposite sides of the column (figure 3). The columns run parallel to the $a$ axis with the ligand planes slanted slightly to this direction. Within the column, pairs of quinolin-8-olate ligands from two adjacent molecules align antiparallel across a centre of inversion with the distance between the planes being approximately 3.6 ̊. The methoxyphenyl ring overlaps almost perfectly the 8quinolyloxy ring of the neighboring ligand, which suggests the presence of significant $\pi \cdots \pi$ interaction; the centroid...centroid distance is 3.713(2) $\AA$, the perpendicular distance from the centroid of one ring to the plane of the other is 3.616(1) $\AA$ and the ring planes are inclined at only $4.5(1)^{\circ}$. However, the next pair of quinolin-8-olate ligands in the column is sufficiently offset from the previous pair to preclude significant $\pi \cdots \pi$ interactions between them. The other quinolin-8-olate ligand does not have any close face-to-face contacts, but its methoxy is involved in a weak $\mathrm{C}-\mathrm{H} \cdots \mathrm{O}$ interaction with the planar quinolin-8-olate ligand of a neighboring molecule, namely with the $\mathrm{C}-\mathrm{H}$ group ortho to oxygen coordinating to $\mathrm{Sn}(\mathrm{O} \cdots \mathrm{H}=2.68 \AA$ and $\mathrm{O} \cdots \mathrm{H}-\mathrm{C}=$ $\left.140^{\circ}\right)$. This interaction links pairs of molecules across centres of inversion and thereby crosslinks the stacks of molecules to give two-dimensional supramolecular sheets which lie parallel to the (101) plane. The $\mathrm{C}-\mathrm{H} \cdots \mathrm{O}$ interaction and the absence of $\pi \cdots \pi$ interactions involving the second quinolin-8-olate may contribute to this ligand being twisted.

In 6, the asymmetric unit contains one molecule of the mononuclear Sn-complex plus one disordered molecule of toluene. The $\mathrm{Sn}$ is five-coordinate (figure 2) and the compound assumes a similar geometry to that observed for its dibutyltin(IV) analogue; the geometric parameters are also very similar [6]. The coordination geometry is best described as distorted cis-trigonal bipyramidal. The bidentate quinolin-8-olate coordinates such that $\mathrm{N}$ and $\mathrm{O}$ are in axial and equatorial positions, respectively. The other axial position is occupied by $\mathrm{Cl}^{-}$and the methyls complete the equatorial plane. Except for the methyl ligands, 6 is essentially planar. The molecules are stacked parallel to the $a$ axis in an alternating antiparallel arrangement and adjacent molecules in the stack are almost perfectly overlapping across centres of inversion with a distance between the planes of approximately $3.3 \AA$. Despite this, the 6-membered rings in adjacent molecules lie mostly offset from one another, reducing the strength of any $\pi \cdots \pi$ interactions. The toluene molecules fill spaces between neighboring stacks. $\mathrm{Cl} \cdots \mathrm{H}-\mathrm{C}$ 
interactions, which involve the quinolin-8-olate $\mathrm{C}-\mathrm{H}$ ortho to $\mathrm{N}$ coordinating to $\mathrm{Sn}(\mathrm{Cl} \cdots \mathrm{H}=$ $2.70 \AA$ and $\mathrm{Cl} \cdots \mathrm{H}-\mathrm{C}=163^{\circ}$ ), link the metal ends of the molecules head-to-head into chains which run parallel to the $b$ axis. In conjunction with the stacks, these interactions complete a three-dimensional supramolecular network (figure 4).

\section{Conclusion}

We have demonstrated that 5-[(E)-2-(aryl)-1-diazenyl)quinolin-8-olates readily combine with dimethyltin to form new coordination complexes of the types $\mathrm{Me}_{2} \mathrm{Sn}(\mathrm{L})_{2}$ and $\mathrm{Me}_{2} \mathrm{SnCl}(\mathrm{L})$. Both spectroscopic and crystal structure results show that $\mathrm{Me}_{2} \mathrm{Sn}(\mathrm{L})_{2}$ were distorted cis-octahedral arrangement while $\mathrm{Me}_{2} \mathrm{SnCl}(\mathrm{L})$ are a distorted trigonal bipyramidal coordination geometry around tin in both solution and solid state. Notably, the reactivity of the related dibutyltin(IV) chloro analogue $\mathrm{Bu}_{2} \mathrm{SnCl}(\mathrm{L})$ demonstrated elegant structural architectures with a range of carboxylate ligands and now $\mathrm{Me}_{2} \mathrm{SnCl}(\mathrm{L})$ is structurally accessible which may provide a route for synthesizing new complexes with various architectures.

\section{Supplementary material}

CCDC--889287-889288 contains the supplementary crystallographic data for $\mathbf{2}$ and $\mathbf{6}$. These data can be obtained free of charge from Cambridge Crystallographic Data Centre via www.ccdc.cam.ac.uk/data_request/cif.

\section{Acknowledgements}

David Wolstenholme, University of New Brunswick, Canada is thanked for his assistance with the crystal strueture determination of compound $\mathbf{6}$ during an exchange visit to the University of Zurich. The financial support of the Department of Science \& Technology, New Delhi, India (Grant No. SR/S1/IC-03/2005,TSBB), the University Grants Commission, New Delhi, India through SAP-DSA, Phase-III and Indo-Swiss Joint Research Programme, Joint Utilisation of Advanced Facilities (Grant No. JUAF 11, TSBB, AL) are gratefully acknowledged.

\section{References}

[1] T.S. Basu Baul, A. Mizar, X. Song, G. Eng, R. Willem, M. Biesemans, I. Verbruggen, R. Butcher. J. Organomet. Chem., 691, 2605 (2006). 
[2] T.S. Basu Baul, A. Mizar, A. Lyčka, E. Rivarola, R. Jirásko, M. Holčapek, D. de Vos, U. Englert. J. Organomet. Chem., 691, 3416 (2006).

[3] T.S. Basu Baul, A. Mizar, A.K. Chandra, X. Song, G. Eng, R. Jirásko, M. Holčapek, D. de Vos, A. Linden. J. Inorg. Biochem., 102, 1719 (2008).

[4] T.S. Basu Baul, A. Mizar, G. Ruisi, E.R.T. Tiekink. Z. Anorg. Allg. Chem., 638, 664 (2012).

[5] T.S. Basu Baul, A. Mizar, E. Rivarola, U. Englert. J. Organomet. Chem., 693, 1751 (2008).

[6] T.S. Basu Baul, A. Mizar, A. Paul, G. Ruisi, R. Willem, M. Biesemans, A. Linden. J. Organomet. Chem., 694, 2142 (2009).

[7] E.O. Schlemper. Inorg. Chem., 6, 2012 (1967).

[8] R. Hooft, KappaCCD Collect Software, Nonius BV, Delft, The Netherlands (1999).

[9] Z. Otwinowski, W. Minor, in: C.W. Carter Jr., R.M. Sweet (Ed.), Methods in Enzymology, vol. 276, Macromolecular Crystallography, Part A, Academic Press, New York, pp. 307-326 (1997).

[10] R.H. Blessing. Acta Crystallogr., Sect. A, 51, 33 (1995).

[11] A. Altomare, G. Cascarano, C. Giacovazzo, A. Guagliardi, M.C. Burla, G. Polidori, M. Camalli, SIR92. J. Appl. Crystallogr, 27, 435 (1994).

[12] G.M. Sheldrick, SHELXL97, Program for the Refinement of Crystal Structures, University of Göttingen, Germany (1997).

[13] T.P. Lockhart, W.F. Manders. Inorg. Chem., 25, 892 (1986).

[14] T.A.K. Al-Allaf. J. Organomet. Chem., 306, 337 (1986).

[15] H.C. Clark, V.K. Jain, I.J. McMahon, R.C. Mehrotra. J. Organomet. Chem., 243, 299 (1983).

[16] V.K. Jain, J. Mason, B.S. Saraswat, R.C. Mehrotra. Polyhedron, 4, 2089 (1985).

[17] J. Otera. J. Organomet. Chem., 221, 57 (1981).

[18] R.V. Parish. Prog. Inorg. Chem., 15, 101 (1972).

[19] R.C. Poller. J. Chem. Soc., Sect. A, 2273 (1969).

[20] K.D. Ghuge, P. Umapathy, M.P. Gupta, D.N. Sen. J. Inorg. Nucl. Chem., 43, 653 (1981).

[21] R.V. Parish, in: Mössabauer Effect: Current Applications to Physical Sciences (Ed.: L.S. Kothari, J.S. Baijal, S.P. Tewari), Academic Publications, Delhi, India, p. 162 (1984). 
[22] R. Barbieri, F. Huber, L. Pellerito, G. Ruisi, A. Silvestri, in: ${ }^{119}$ Sn Mössbauer Studies on Tin Compounds: Chemistry of Tin, P.J. Smith (Ed.), Blackie Academic \& Professional, London, pp. 496-540 (1998).

[23] R.C. Poller, J.N.R. Ruddick. J. Chem. Soc. (A), 2273 (1969).

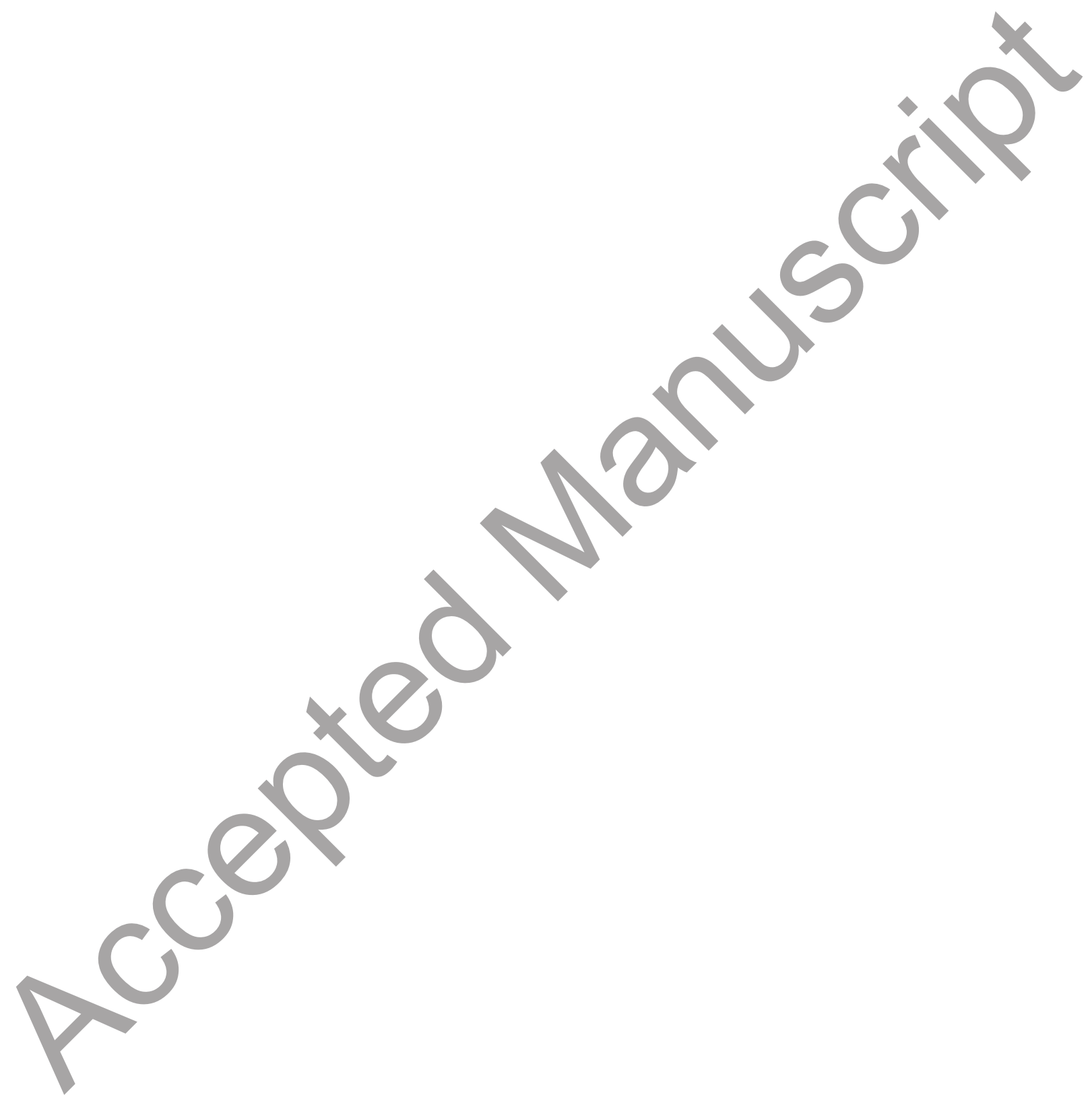


Table 1. Crystal data, data collection and refinement parameters for $\mathbf{2}$ and $\mathbf{6}$.

\begin{tabular}{|c|c|c|}
\hline & 2 & 6 \\
\hline Empirical formula & $\mathrm{C}_{34} \mathrm{H}_{30} \mathrm{~N}_{6} \mathrm{O}_{4} \mathrm{Sn}$ & $\mathrm{C}_{26} \mathrm{H}_{28} \mathrm{ClN}_{3} \mathrm{O}_{2} \mathrm{Sn}$ \\
\hline Formula weight & 705.25 & 568.58 \\
\hline Crystal size (mm) & $0.08 \times 0.15 \times 0.30$ & $0.25 \times 0.25 \times 0.28$ \\
\hline Crystal shape & Prism & Prism \\
\hline Temperature (K) & $160(1)$ & $160(1)$ \\
\hline Crystal system & Triclinic & Monoclinic \\
\hline Space group & $P \overline{1}$ & D2 10 \\
\hline$a(\AA)$ & $8.8379(2)$ & $3050(1)$ \\
\hline$b(\AA)$ & $13.5486(4)$ & $2826(2)$ \\
\hline$c(\AA)$ & $14.0739(4)$ & $33.2846(6)$ \\
\hline$\alpha\left({ }^{\circ}\right)$ & $73.047(1)$ & 90 \\
\hline$\beta\left(\left(^{\circ}\right)\right.$ & $74184(2)$ & $91.2367(6)$ \\
\hline$\gamma\left({ }^{\circ}\right)$ & & 90 \\
\hline$V\left(\AA^{3}\right)$ & 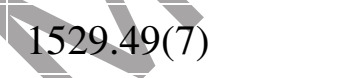 & 2499.57(7) \\
\hline$Z$ & 2 & 4 \\
\hline$D_{x}\left(\mathrm{~g} \mathrm{~cm}^{-3}\right)$ & 1.531 & 1.511 \\
\hline$\mu\left(\mathrm{mm}^{-1}\right)$ & 0.884 & 1.156 \\
\hline Transmission factors (min, max) & $0.858,0.943$ & $0.672,0.756$ \\
\hline $2 \theta_{\max }\left(^{\circ}\right)$ & 55 & 60 \\
\hline Reflections measured & 34008 & 50914 \\
\hline Indep. reflections $\left(R_{\text {int }}\right)$ & $7034(0.064)$ & $7282(0.058)$ \\
\hline Indep. reflections with $I>2 \sigma(I)$ & 5791 & 5968 \\
\hline Number of parameters; restraints & $411 ; 0$ & $368 ; 273$ \\
\hline$R(F)(I>2 \sigma(I)$ reflns. $)$ & 0.0385 & 0.0319 \\
\hline$w R 2\left(F^{2}\right)$ (all data) & 0.0884 & 0.0752 \\
\hline$G O F\left(F^{2}\right)$ & 1.107 & 1.081 \\
\hline $\operatorname{Max}, \min \Delta \rho\left(\mathrm{e} / \AA^{3}\right)$ & $1.03,-0.87$ & $1.13,-0.80$ \\
\hline
\end{tabular}


Table 2. Selected bond lengths $(\AA)$ and angles $\left(^{\circ}\right)$ for $\mathrm{Me}_{2} \mathrm{Sn}\left(\mathrm{L}^{2}\right)_{2}(\mathbf{2})$.

\begin{tabular}{llll}
\hline $\mathrm{Sn}(1)-\mathrm{C}(21)$ & $2.149(3)$ & $\mathrm{O}(2)-\mathrm{Sn}(1)-\mathrm{N}(1)$ & $85.88(7)$ \\
$\mathrm{Sn}(1)-\mathrm{C}(31)$ & $2.139(3)$ & $\mathrm{O}(2)-\mathrm{Sn}(1)-\mathrm{N}(2)$ & $74.32(7)$ \\
$\mathrm{Sn}(1)-\mathrm{O}(1)$ & $2.108(2)$ & $\mathrm{O}(1)-\mathrm{Sn}(1)-\mathrm{O}(2)$ & $153.95(7)$ \\
$\mathrm{Sn}(1)-\mathrm{O}(2)$ & $2.093(2)$ & $\mathrm{C}(21)-\mathrm{Sn}(1)-\mathrm{N}(1)$ & $84.99(9)$ \\
$\mathrm{Sn}(1)-\mathrm{N}(1)$ & $2.388(2)$ & $\mathrm{C}(21)-\mathrm{Sn}(1)-\mathrm{N}(2)$ & $156.13(9)$ \\
$\mathrm{Sn}(1)-\mathrm{N}(2)$ & $2.334(2)$ & $\mathrm{C}(31)-\mathrm{Sn}(1)-\mathrm{N}(1)$ & $158.5(1)$ \\
$\mathrm{N}(1)-\mathrm{C}(9)$ & $1.358(3)$ & $\mathrm{C}(31)-\mathrm{Sn}(1)-\mathrm{N}(2)$ & $89.8(1)$ \\
$\mathrm{N}(2)-\mathrm{C}(19)$ & $1.365(3)$ & $\mathrm{C}(21)-\mathrm{Sn}(1)-\mathrm{C}(31)$ & $112.8(1)$ \\
$\mathrm{N}(3)-\mathrm{N}(4)$ & $1.263(3)$ & $\mathrm{O}(1)-\mathrm{Sn}(1)-\mathrm{C}(21)$ & $100.92(9)$ \\
$\mathrm{N}(5)-\mathrm{N}(6)$ & $1.254(3)$ & $\mathrm{O}(1)-\mathrm{Sn}(1)-\mathrm{C}(31)$ & $91.3(1)$ \\
& & $\mathrm{O}(2)-\mathrm{Sn}(1)-\mathrm{C}(21)$ & $91.86(9)$ \\
$\mathrm{O}(1)-\mathrm{Sn}(1)-\mathrm{N}(1)$ & $72.89(7)$ & $\mathrm{O}(2)-\mathrm{Sn}(1)-\mathrm{C}(31)$ & $104.7(1)$ \\
$\mathrm{O}(1)-\mathrm{Sn}(1)-\mathrm{N}(2)$ & $85.46(8)$ & $\mathrm{N}(1)-\mathrm{Sn}(1)-\mathrm{N}(2)$ & $74.86(7)$ \\
\hline
\end{tabular}


Table 3. Selected bond lengths $(\AA)$ and angles $\left({ }^{\circ}\right)$ for $\mathrm{Me}_{2} \mathrm{SnCl}\left(\mathrm{L}^{3}\right) \cdot \mathrm{C}_{7} \mathrm{H}_{8}(\mathbf{6})$.

\begin{tabular}{llll}
\hline $\mathrm{Sn}(1)-\mathrm{O}(1)$ & $2.053(2)$ & $\mathrm{C}(18)-\mathrm{Sn}(1)-\mathrm{C}(19)$ & $128.8(1)$ \\
$\mathrm{Sn}(1)-\mathrm{N}(1)$ & $2.343(2)$ & $\mathrm{O}(1)-\mathrm{Sn}(1)-\mathrm{N}(1)$ & $74.66(6)$ \\
$\mathrm{Sn}(1)-\mathrm{Cl}$ & $2.4724(6)$ & $\mathrm{C}(18)-\mathrm{Sn}(1)-\mathrm{N}(1)$ & $91.00(8)$ \\
$\mathrm{Sn}(1)-\mathrm{C}(18)$ & $2.113(2)$ & $\mathrm{C}(19)-\mathrm{Sn}(1)-\mathrm{N}(1)$ & $93.04(8)$ \\
$\mathrm{Sn}(1)-\mathrm{C}(19)$ & $2.113(2)$ & $\mathrm{O}(1)-\mathrm{Sn}(1)-\mathrm{Cl}$ & $85.69(4)$ \\
$\mathrm{O}(1)-\mathrm{C}(1)$ & $1.336(2)$ & $\mathrm{C}(18)-\mathrm{Sn}(1)-\mathrm{Cl}$ & $97.15(7)$ \\
$\mathrm{N}(1)-\mathrm{C}(8)$ & $1.323(3)$ & $\mathrm{C}(19)-\mathrm{Sn}(1)-\mathrm{Cl}$ & $95.68(7)$ \\
$\mathrm{N}(1)-\mathrm{C}(9)$ & $1.363(3)$ & $\mathrm{N}(1)-\mathrm{Sn}(1)-\mathrm{Cl}$ & $160.35(5)$ \\
& & $\mathrm{C}(1)-\mathrm{O}(1)-\mathrm{Sn}(1)$ & $119.4(1)$ \\
$\mathrm{O}(1)-\mathrm{Sn}(1)-\mathrm{C}(18)$ & $115.17(8)$ & $\mathrm{C}(8)-\mathrm{N}(1)-\mathrm{Sn}(1)$ & $130.6(2)$ \\
$\mathrm{O}(1)-\mathrm{Sn}(1)-\mathrm{C}(19)$ & $115.11(8)$ & $\mathrm{C}(9)-\mathrm{N}(1)-\mathrm{Sn}(1)$ & $110.3(1)$ \\
\hline
\end{tabular}




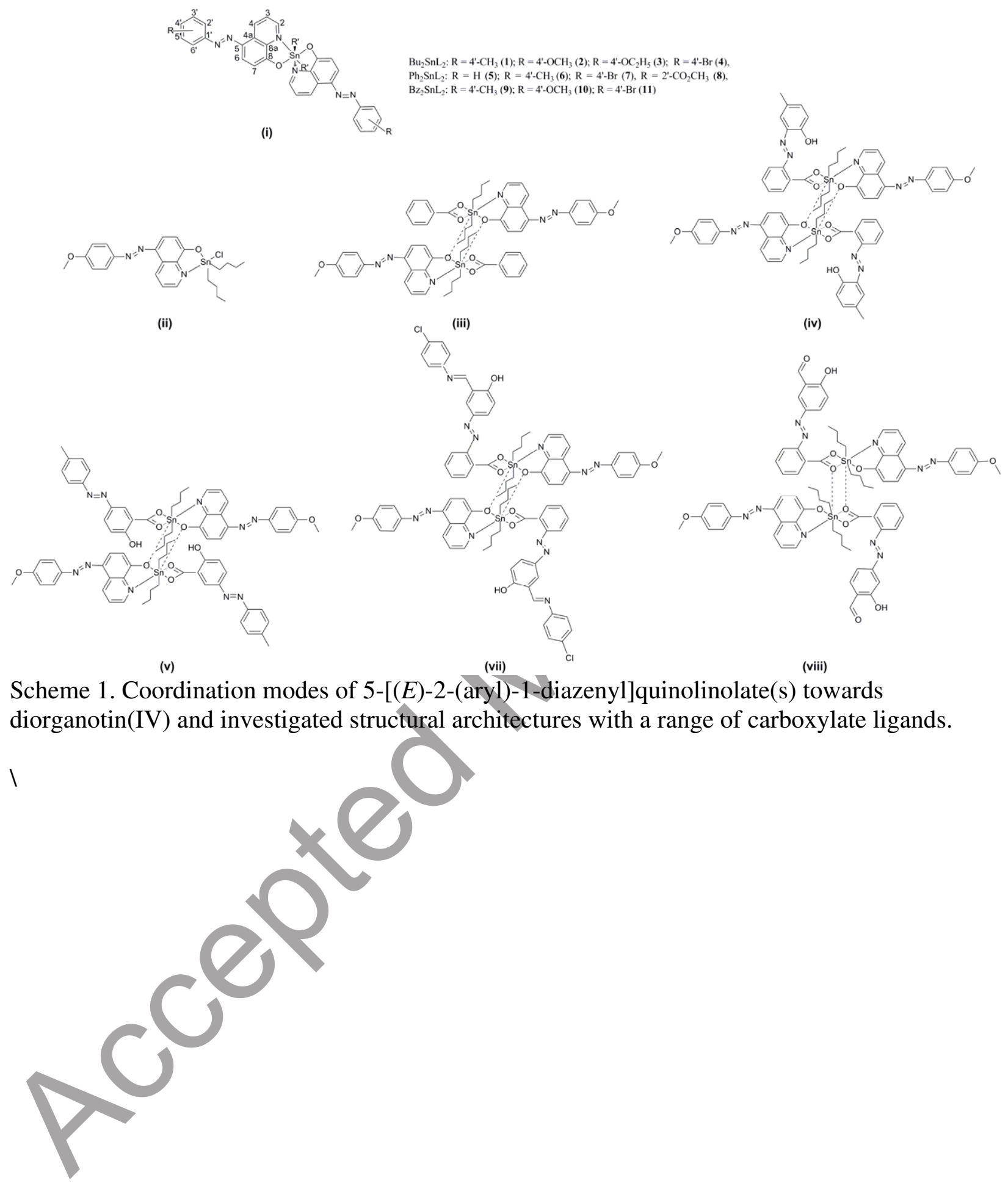




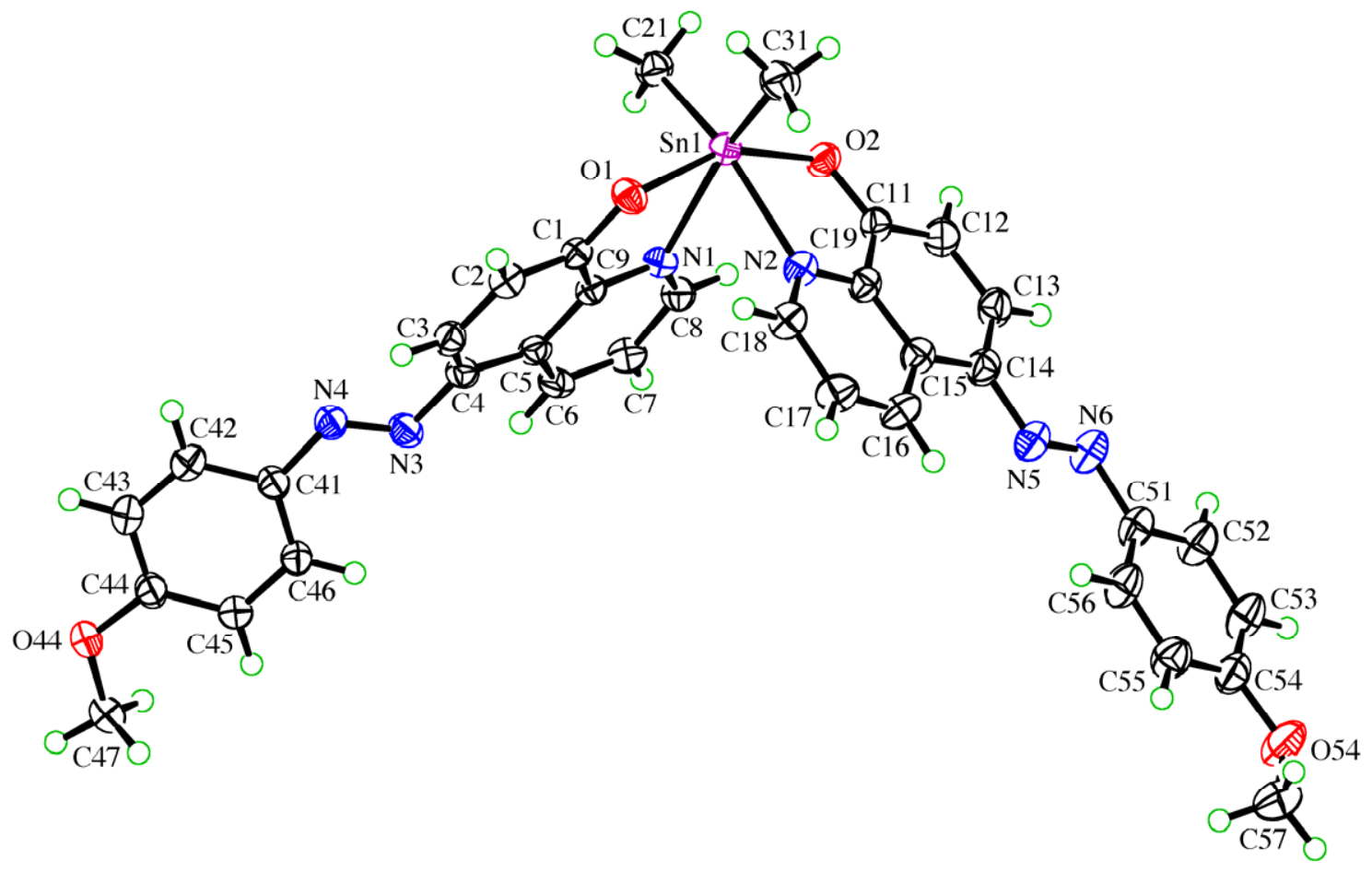

Figure 1. The molecular structure of $\mathrm{Me}_{2} \mathrm{Sn}\left(\mathrm{L}^{2}\right)_{2}$ (2). Displacement ellipsoids are shown at the $50 \%$ probability level. 


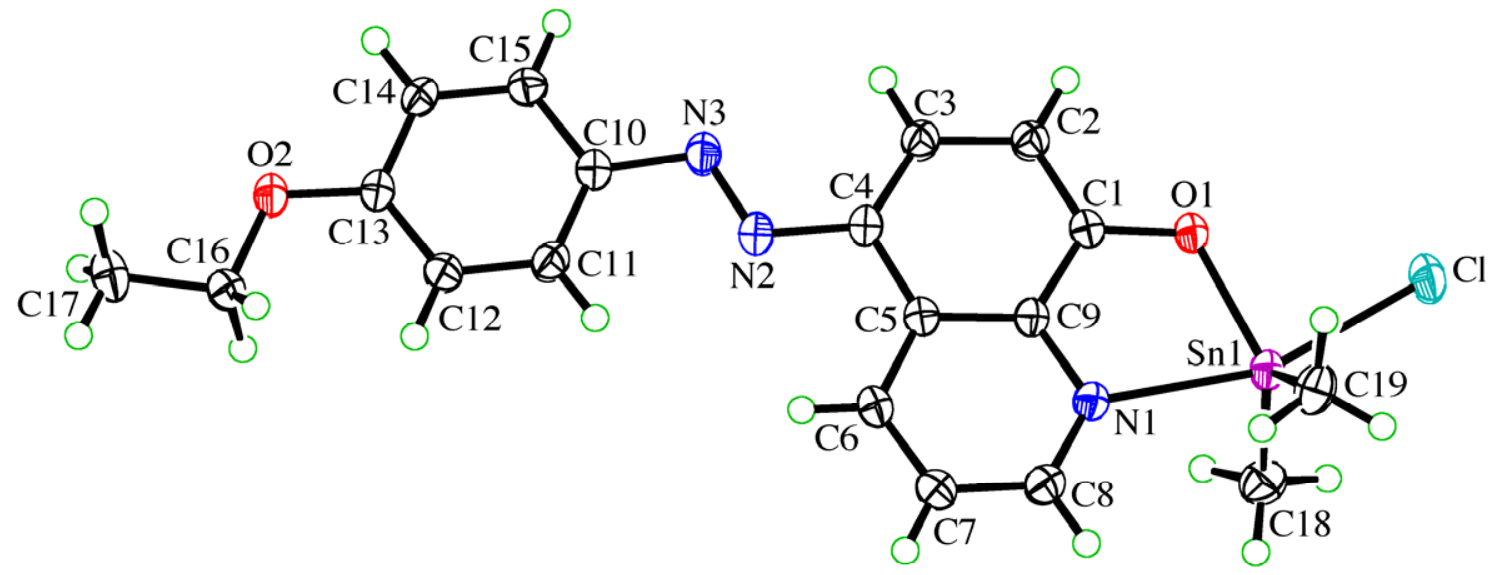

Figure 2. The molecular structure of $\mathrm{Me}_{2} \mathrm{SnCl}\left(\mathrm{L}^{3}\right) \cdot \mathrm{C}_{7} \mathrm{H}_{8}(6)$. Displacement ellipsoids are shown at the $50 \%$ probability level. 


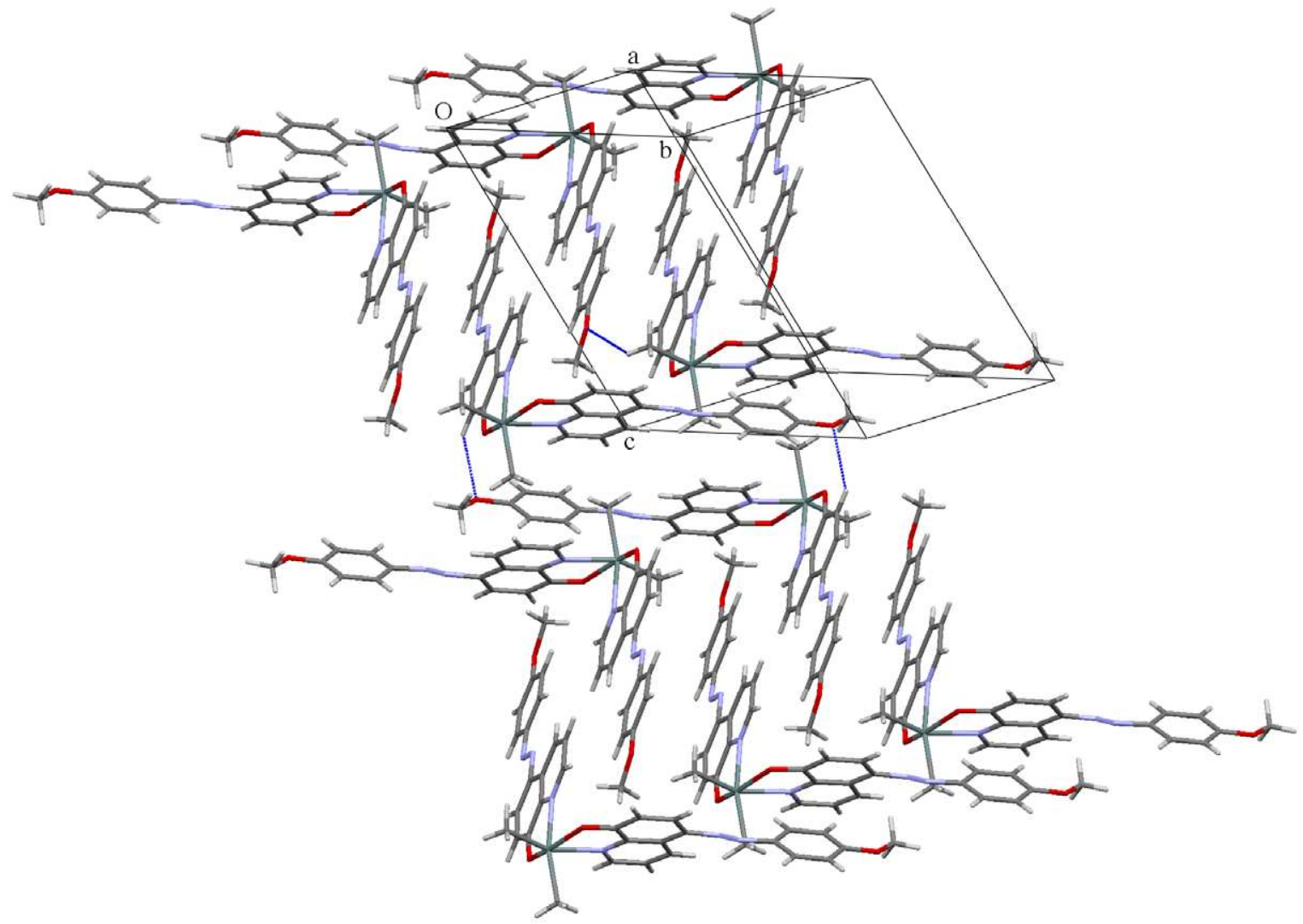

Figure 3. The crystal packing of $\mathrm{Me}_{2} \mathrm{Sn}\left(\mathrm{L}^{2}\right)_{2}$ (2) showing stacks formed by the planar ligands and the $\mathrm{C}-\mathrm{H} \cdots \mathrm{O}$ interactions (blue lines) cross-linking the stacks. 


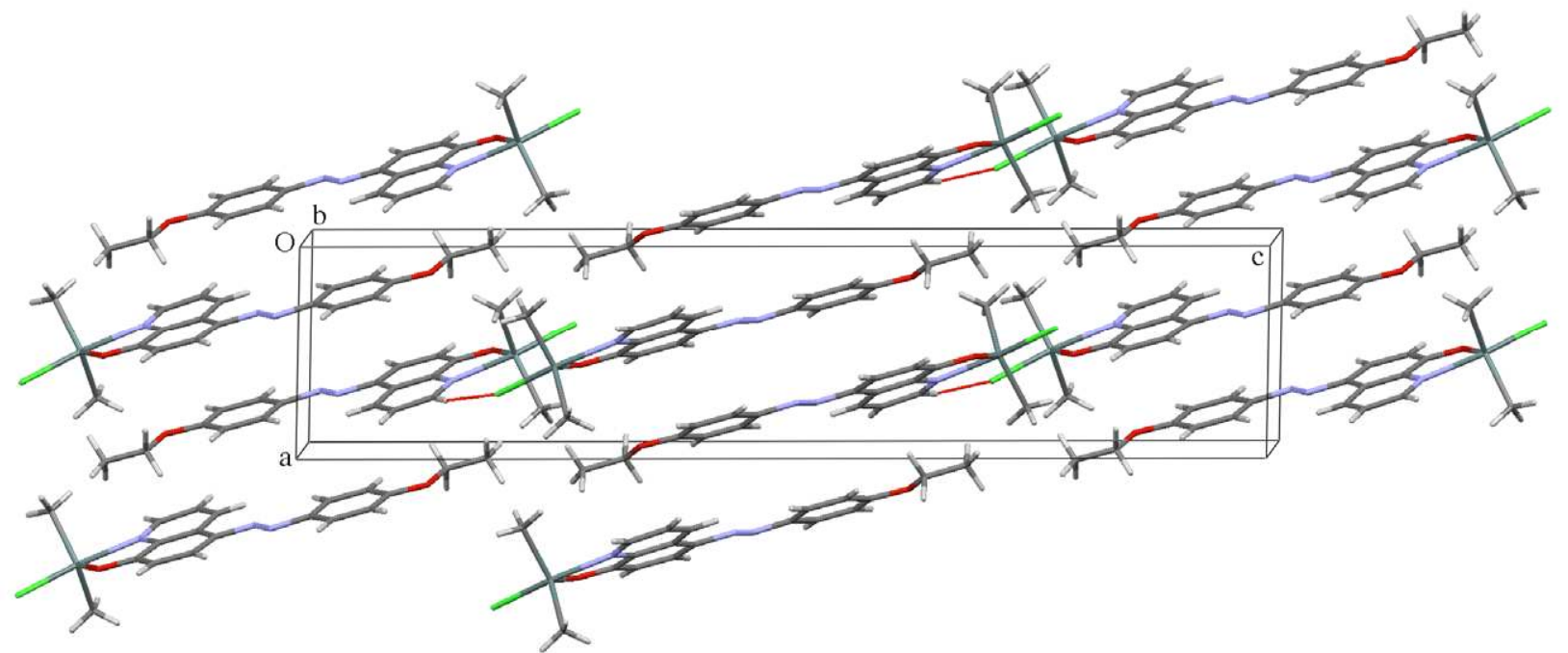

Figure 4. The crystal packing of $\mathrm{Me}_{2} \mathrm{SnCl}\left(\mathrm{L}^{3}\right) \cdot \mathrm{C}_{7} \mathrm{H}_{8}(6)$ showing stacks formed by the planar ligands and the $\mathrm{C}-\mathrm{H} \cdots \mathrm{Cl}$ interactions (red lines) cross-linking the stacks parallel to the $b$ axis. The solvent molecules have been omitted for clarity. 